\title{
A chemosensor for dihydrogenphosphate based on an oxoazamacrocycle possessing three thiourea arms
}

\author{
Anxela Aldrey, ${ }^{\mathrm{a}}$ Alejandro Macías, ${ }^{\mathrm{a}}$ Rufina Bastida, ${ }^{* \mathrm{a}}$ Guillermo Zaragoza, ${ }^{\mathrm{b}}$ Gustavo Rama ${ }^{\mathrm{c}}$ and Miguel \\ Vázquez López*c
}

\author{
${ }_{5}$ Received (in XXX, XXX) Xth XXXXXXXXX 200X, Accepted Xth XXXXXXXXX 200X \\ First published on the web Xth $X X X X X X X X X 200 X$ \\ DOI: $10.1039 / \mathbf{b 0 0 0 0 0 0 x}$
}

We report a new H-bond macrocyclic chromogenic chemosensor in organic media, $\mathbf{H}_{3} \mathbf{L}$, which displayed drastic changes in the UV-Vis spectra revealing selectivity for dihydrogenphosphate 10 over other inorganic anions, such as acetate or fluoride. The X-ray crystal structures of the

$\left[\mathbf{H}_{4} \mathbf{L} \cdots \mathrm{NO}_{3}\right] \cdot\left(\mathrm{CH}_{3} \mathrm{CN}\right)_{4}$ and $\left[\mathbf{H}_{4} \mathbf{L} \cdots \mathrm{CF}_{3} \mathrm{CO}_{2}\right] \cdot\left(\mathrm{CH}_{3} \mathrm{CN}\right)_{2}$ salt complexes are also reported.

\section{Introduction}

The molecular recognition and sensing of anionic analytes is an area of increasing research activity, mainly because of the 15 importance of these species in many biological and chemical processes. ${ }^{1}$ Sensing of phosphates and their derivatives is of special importance as they compose the backbone of DNA and RNA and also play crucial roles in signal transduction and energy storage in biological systems. ${ }^{2}$ Even though a number 20 of sensors for phosphate anions have been reported, ${ }^{1,3}$ there is still a need for simple receptors with improved optical response and selectivity.

Most chemosensors for inorganic anions that work in organic media are neutral receptors equipped with $\mathrm{NH}$ ${ }_{25}$ recognition units, such as ureas, ${ }^{4}$ thioureas, ${ }^{5}$ amides, ${ }^{6}$ sulfonamides $^{7}$ and pyrroles. ${ }^{8}$ The $\mathrm{NH}$ groups of these devices usually act as H-bond donors, and the anion as an H-bond aceptor. ${ }^{9}$ The more acidic the donor, or the more basic the aceptor, the stronger the hydrogen bonding interaction. In a 30 limiting situation, exceptionally acidic donors may be deprotonated on reaction with strongly basic aceptors. ${ }^{10}$ For fluoride anions the deprotonation process is also favoured due to the formation of the highly stable $\left[\mathrm{HF}_{2}\right]^{-}$selfcomplex. ${ }^{11}$ Acetate and phosphate anions can also promote 35 the formation of $\left[\mathrm{HX}_{2}\right]^{-}$dimers, but their stability is lower. ${ }^{12}$ This explains why most of this class of chemosensors display greater response along the series $\mathrm{F}^{-}>\mathrm{CH}_{3} \mathrm{CO}_{2}^{-}>\mathrm{H}_{2} \mathrm{PO}_{4}^{-13}$ although the selectivity between $\mathrm{F}^{-}$and $\mathrm{CH}_{3} \mathrm{CO}_{2}^{-}$is often poor. ${ }^{14}$ In this context, we have recently demonstrated how 40 selectivity for fluoride can be enhanced by using an imine group as an intramolecular H-bond modulator. ${ }^{15}$ However, examples of $\mathrm{H}$-bond receptors that show selectivity to dihydrogephosphate against acetate or fluoride are very scarce. $^{12 \mathrm{~b}, 16}$

${ }_{45}$ We present a new thiourea-based oxo-azamacrocyclic chemosensor (Scheme 1, $\mathbf{H}_{\mathbf{3}} \mathbf{L}$ ) which allows naked-eye detection of fluoride, acetate and dihydrogenphosphate anions in $\mathrm{MeCN}$ solution. This receptor shows high sensitivity for $\mathrm{F}^{-}, \mathrm{CH}_{3} \mathrm{CO}_{2}^{-}$and $\mathrm{H}_{2} \mathrm{PO}_{4}^{-}$and, surprisingly,

50 displays selectivity towards $\mathrm{H}_{2} \mathrm{PO}_{4}^{-}$against the other two anions. The $\mathrm{X}$-ray crystal structures of the $\left[\mathbf{H}_{4} \mathbf{L} \cdot \mathrm{NO}_{3}\right] \cdot\left(\mathrm{CH}_{3} \mathrm{CN}\right)_{4}$ and $\left[\mathbf{H}_{4} \mathbf{L} \cdot \mathrm{CF}_{3} \mathrm{CO}_{2}\right] \cdot\left(\mathrm{CH}_{3} \mathrm{CN}\right)_{2}$ salt complexes are also discussed.

\section{Experimental section}

\section{${ }_{55}$ General information}

Chemicals and solvents of the highest commercial grade available were used as received. Oxaazamacrocycle 1 was synthesized as described in the literature. ${ }^{17}$

High-Perfomance Liquid Chromatography (HPLC) was ${ }_{60}$ made using an Agilent 1100 series LC/MSD instrument. Analitical HPLC was run using a Phenomenex Luna C18 (250 x $4.60 \mathrm{~mm}$ ) analytical reverse phase column using an Agilent 1100 HPLC equipped with a Mass Spectrometry detector Agilent LC/MSD VL. The purification of $\mathbf{H}_{3} \mathbf{L}$ was performed ${ }_{65}$ on a Phenomenex Luna C18 $(250 \times 10 \mathrm{~mm})$ semi-preparative reverse phase column. Standard conditions for analytical RPHPLC consisted of an isocratic regime during the first 5 minutes, followed by a linear gradient from 15 to $95 \%$ of solvent $\mathrm{B}$ for 30 minutes at a flow of $1 \mathrm{~mL} / \mathrm{min}$ with a 70 Retention Time (RT) for the ligand of 27.2 minutes and a $\mathrm{m} / \mathrm{z}$ ratio of 925.1 corresponding to the quasy-molecular ion $[\mathrm{M}+\mathrm{H}]^{+}$. For the purification in the semi-preparative scale, we used a gradient from $50-85 \%$ of solvent B for 30 minutes at a flow of $3 \mathrm{~mL} / \mathrm{min}$, in this conditions the RT reduced to 19.0 75 minutes. A: water with $0.1 \%$ Trifluoroacetic acid; B: Acetonitrile with $0.1 \%$ Trifuoroacetic acid.

FAB mass spectrometry (FAB-MS) was performed on a Micromass Autospec spectrometer employing $m$-nitrobenzyl alcohol as matrix. Electrospray ionization mass spectrometry 80 (ESI-MS) was performed on an Agilent 1100 Series LC/MSD instrument in positive scan mode using direct injection. Elemental analyses were performed on a Carlo Erba EA 1108 analyzer. NMR spectra were recorded on a Bruker AMX-500 spectrometer, using deuterated $\mathrm{CD}_{3} \mathrm{CN}$ as solvent. UV-vis ${ }_{85}$ spectra were performed on a JASCO V-630 spectrophotometer equipped with a Peltier thermostat. All the UV-vis titrations experiments were performed on $2 \mathrm{~mL}$ samples of solutions of the receptor $(20 \mu \mathrm{M})$ in $\mathrm{CH}_{3} \mathrm{CN}$, by addition of $\mathrm{CH}_{3} \mathrm{CN}$ stock solutions of appropiate anion in the form of 90 tetrabutylammonium salts. The UV/Vis titration data were fitted using the SPECTFIT/32 and the HYPERCHEM programmes. 
Crystal structure determinations were performed at low temperature $(100 \mathrm{~K})$ with a Bruker APEXII CCD diffractometer, using graphite-monochromated Mo-K $\alpha$ 5 radiation from a fine focus sealed tube source. All Computing data and reduction was made with the APPEX II software. Empirical absorption corrections were also applied. ${ }^{18}$ The structures were solved by direct methods using SIR-97, ${ }^{19}$ and finally refined by full-matrix, least-squares based on $\mathrm{F}^{2}$ by ${ }_{10}$ SHELXL. $^{20}$ All non hydrogen atoms were anisotropically refined and the hydropen atoms positions geometically calculed and refined using a riding model, except the hydrogen atoms of $\mathrm{N}-\mathrm{H}$ groups involved in $\mathrm{H}$-Bonds that were located in a difference map and its position refined 15 isotropically $[\mathrm{Uiso}(\mathrm{H})=1.2 \mathrm{Ueq}(\mathrm{O})]$.

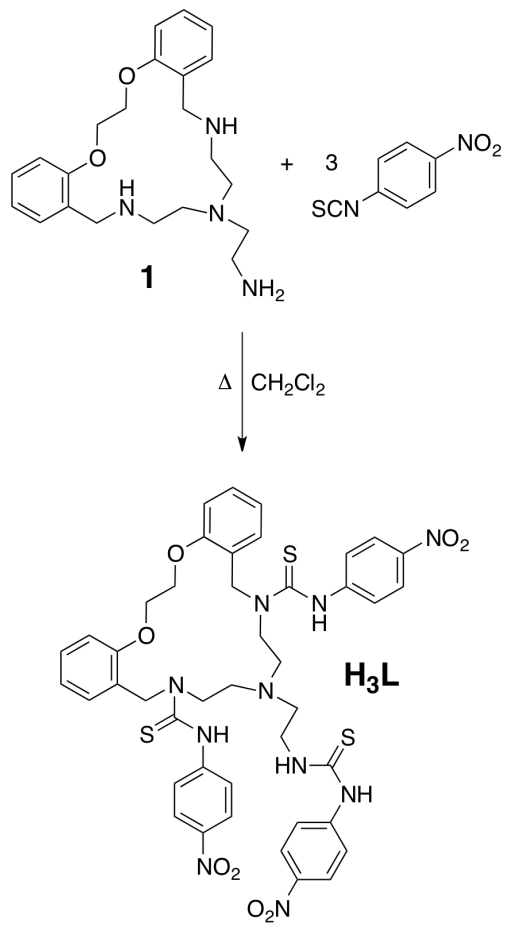

Scheme 1. Synthesis of $\mathbf{H}_{3} \mathbf{L}$.

\section{Synthesis}

Receptor $\mathrm{H}_{3} \mathrm{~L}$ synthesis (Scheme 1): A solution of 420 nitrophenylisothiocyanate $(0.5 \mathrm{~g}, 3 \mathrm{mmol})$ in dry $\mathrm{CH}_{2} \mathrm{Cl}_{2}(25$ $\mathrm{mL}$ ) was added dropwise to a refluxing solution of the oxaazamacrocycle $1(0.38 \mathrm{~g}, 1 \mathrm{mmol})$ in the same solvent $(25 \mathrm{~mL})$. The resulting solution was refluxed with magnetic stirring for $24 \mathrm{~h}$, and then evaporated to dryness 25 under reduced pressure. The solid residue was dissolved in $\mathrm{CHCl}_{3}$ and extracted with deionized water. The organic phase was dried with $\mathrm{MgSO}_{4}$, filtered and concentrated to dryness in a rotatory evaporator. The yellow solid residue was purified by HPLC using $\mathrm{MeOH} / \mathrm{H}_{2} \mathrm{O} 0.1 \%$ TFA as eluent.

${ }_{30}$ Collected fractions were partly concentrated under reduced pressure at $30{ }^{\circ} \mathrm{C}$ to eliminate the $\mathrm{MeOH}$, then frozen and freeze dried, using a Thermo ModulyoD drier from Thermo Scientific, to give the desired product as a TFA salt. This salt was dissolved in water, neutralized with $\mathrm{NaOH} 1 \mathrm{M}$ and
35 extracted with dichloromethane. The organic phases were dried $\left(\mathrm{MgSO}_{4}\right)$, filtered and concentrated to dryness under reduced pressure to give the desired pure product, confirmed by ESI+-MS (see ESI).

Yield: $65 \%$. Anal. Found: C, 53.5; H, 5.1; N, 14.5; S, 10.2; ${ }_{40}$ Calc. for $\mathrm{C}_{43} \mathrm{H}_{44} \mathrm{~N}_{10} \mathrm{O}_{8} \mathrm{~S}_{3} .2 \mathrm{H}_{2} \mathrm{O}: \mathrm{C}, 53.7 ; \mathrm{H}, 5.0 ; \mathrm{N}, 14.6 ; \mathrm{S}$, 10.0 Mass spectrometry (FAB): $m / z=925\left[\mathrm{H}_{3} \mathrm{~L}+\mathrm{H}\right]^{+}$. Mass spectrometry (ESI): $\mathrm{m} / \mathrm{z}=925.3\left[\mathrm{H}_{3} \mathrm{~L}+\mathrm{H}\right]^{+} .{ }^{1} \mathrm{H}$ NMR $(500$ $\left.\mathrm{MHz}, \mathrm{CD}_{3} \mathrm{CN}, 25{ }^{\circ} \mathrm{C}, \mathrm{ppm}\right): 8.86(\mathrm{~s}), 8.03(\mathrm{~m}, 6 \mathrm{H}), 7.61(\mathrm{~d}$, 2H), $7.49(\mathrm{~d}, 4 \mathrm{H}), 7.29(\mathrm{t}, 2 \mathrm{H}), 7.24(\mathrm{~d}, 2 \mathrm{H}), 7.02(\mathrm{~m}, 4 \mathrm{H})$, ${ }_{45} 5.14(\mathrm{~s}, 4 \mathrm{H}), 4.38(\mathrm{~s}, 4 \mathrm{H}), 3.96(\mathrm{~s}, 4 \mathrm{H}), 3.66(\mathrm{~s}, 2 \mathrm{H}), 2.91(\mathrm{~s}$, $4 \mathrm{H}), 2.85(\mathrm{t}, 2 \mathrm{H}) . \lambda_{\max }\left(\varepsilon, \mathrm{CH}_{3} \mathrm{CN}\right)=345\left(36250 \mathrm{M}^{-1} \mathrm{~cm}^{-1}\right)$ nm.

\section{Results and discussion}

\section{Synthesis of $\mathrm{H}_{3} \mathrm{~L}$}

${ }_{50}$ Oxaazamacrocycle $\mathbf{1}$ was prepared following a previously reported method. ${ }^{20}$ Reaction of primary and secondary amines of 1 with 4-nitrophenylisothiocyanate in dry $\mathrm{CH}_{2} \mathrm{Cl}_{2}$ resulted in free receptor $\mathbf{H}_{3} \mathbf{L}$ (Scheme 1). This compound was purified by semi-preparative HPLC and characterized by a variety of 55 techniques, including FAB and ESI mass spectrometry, $\mathrm{UV} / \mathrm{V}$ is and ${ }^{1} \mathrm{H}$ NMR spectroscopy and elemental analysis (see ESI).

$\mathbf{H}_{3} \mathbf{L}$ is composed of a 17 -membered oxoazamacrocycle skeleton equipped with three thiourea arms, two of them ${ }_{60}$ directly attached to the macrocycle body, with which they share a nitrogen atom, and the other one linked to the remaining nitrogen atom of the macrocycle through an alkyl spacer.

\section{Anion binding studies}

${ }_{65}$ The interaction of $\mathbf{H}_{3} \mathbf{L}$ with a variety of inorganic anions was studied by UV/Vis titrations, which were performed in $\mathrm{MeCN}$ by addition of a standard solution of the corresponding tetraalkylammonium salt of the corresponding anion to a 20 $\mu \mathrm{M}$ solution of the receptor.

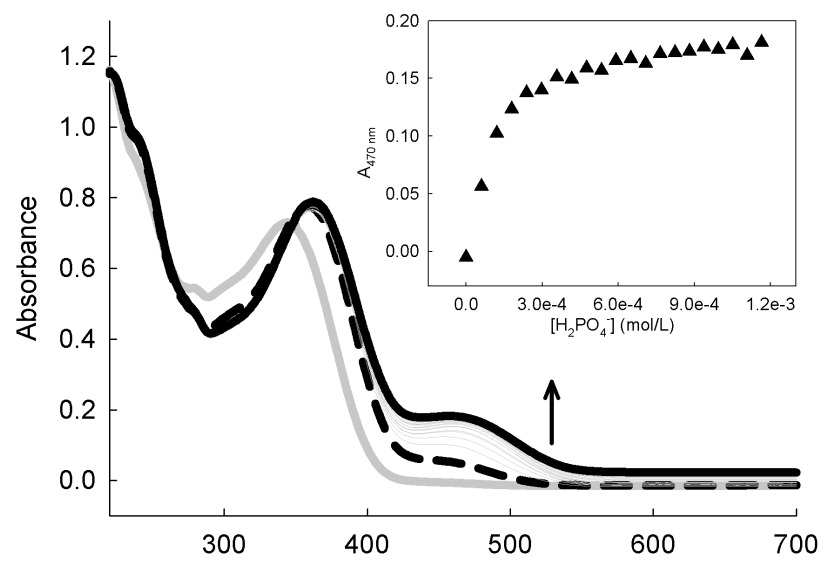

Figure 1. Spectrophotometric titration of a $\mathrm{CH}_{3} \mathrm{CN}$ solution $20 \mu \mathrm{M}$ in $\mathbf{H}_{3} \mathbf{L}$ with a standard solution of dihydrogenphosphate ions. Inset: absorbance at $470 \mathrm{~nm} v s$. concentration of dihydrogenphosphate ions.

Figure 1 displays the family of absorption spectra obtained 75 during titration of $\mathbf{H}_{3} \mathbf{L}$ with dihydrogenphosphate. The 
absorption spectrum of $\mathbf{H}_{3} \mathbf{L}$ in acetonitrile has one band with a maximum at $345 \mathrm{~nm}$, assigned to the charge transfer transition from thiourea to nitrobenzene. Titration with $\mathrm{H}_{2} \mathrm{PO}_{4}{ }^{-}$resulted in an initial red shift of the band at $345 \mathrm{~nm}$ ${ }_{5}$ and the formation of a new intense CT band at $470 \mathrm{~nm}$, with an isosbestic point at $380 \mathrm{~nm}$. A titration profile, obtained by plotting the molar absorbance at $470 \mathrm{~nm}$ vs. the concentration of $\mathrm{H}_{2} \mathrm{PO}_{4}{ }^{-}$in the media, is shown in the inset. This new band at $470 \mathrm{~nm}$ matches well with the absorption band generated 10 when $\mathbf{H}_{3} \mathbf{L}$ reacts with tetrabutylammonium hydroxide, and can be assigned to the deprotonated receptor $\mathbf{L}^{3-}$ (see ESI). Moreover, the addition of dihydrogenphosphate or hidroxide induced a change in the color of the solution from pale to bright yellow (see ESI).

15 Analogous tiration experiments were also carried out with $\mathrm{F}^{-}, \mathrm{CH}_{3} \mathrm{CO}_{2}^{-}, \mathrm{HSO}_{4}^{-}, \mathrm{Cl}^{-}, \mathrm{Br}^{-}, \mathrm{I}^{-}$and $\mathrm{NO}_{3}^{-}$(see ESI). We observed that only $\mathrm{CH}_{3} \mathrm{CO}_{2}^{-}$and $\mathrm{F}^{-}$were able to deprotonate $\mathbf{H}_{3} \mathbf{L}$ in a similar way to $\mathrm{H}_{2} \mathrm{PO}_{4}^{-}$. However, spectral modifications on titration with $\mathrm{HSO}_{4}^{-}, \mathrm{Cl}^{-}, \mathrm{Br}^{-}, \mathrm{I}^{-}$and $\mathrm{NO}_{3}^{-}$ 20 were very moderate, even after the addition of a large excess of anions, suggesting that only H-bonding takes places but not deprotonation.

The initial red shift of the bands at $345 \mathrm{~nm}$ suggests that the receptor $\mathbf{H}_{3} \mathbf{L}$ forms $\mathrm{H}$-bonded adducts with $\mathrm{H}_{2} \mathrm{PO}_{4}^{-}, \mathrm{CH}_{3} \mathrm{CO}_{2}^{-}$ ${ }_{25}$ and $\mathrm{F}^{-}$, when the anion concentration in the media is low. ${ }^{46,21}$ In order to gain some insight about these processes, we decided to carry out further UV-vis titration experiments in the range between 0-10 eq. of the corresponding anion (see ESI). In the three experiments, the $345 \mathrm{~nm}$ band of $\mathbf{H}_{3} \mathbf{L}$ 30 undergoes a bathochromic shift after the addition of the corresponding anion. In the case of $\mathrm{F}^{-}$and $\mathrm{CH}_{3} \mathrm{CO}_{2}^{-}$, the formation of the $470 \mathrm{~nm}$ band is observed even at very low concentration, indicating that the depropotation processes are competing with the adduct formation. However, the formation 35 of this new band is not observed during the titration experiment with $\mathrm{H}_{2} \mathrm{PO}_{4}^{-}$. These results suggest that the $\mathrm{H}-$ bonded adduct formation is favoured for dyhidrogenphosphate with respect to fluoride or acetate.

\section{${ }_{40}$ NMR studies}

+10 eq. $\mathrm{H}_{2} \mathrm{PO}_{4}$

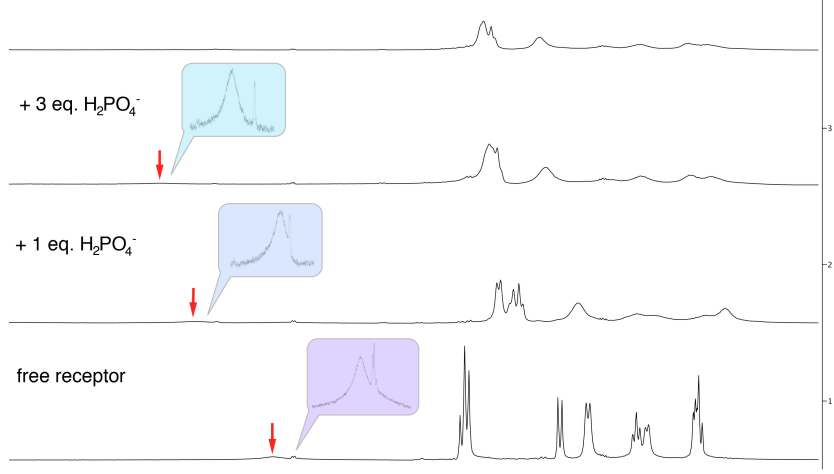

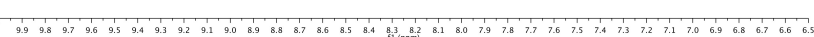

Figure 2. ${ }^{1} \mathrm{H}$ NMR spectra taken over the course of the titration of a $\mathrm{CD}_{3} \mathrm{CN}$ solution of $\mathbf{H}_{3} \mathbf{L}(0.6 \mathrm{mM})$ with a standard solution of $\left[\mathrm{NBu}_{4}\right] \mathrm{H}_{2} \mathrm{PO}_{4}$.
${ }_{45}$ The ${ }^{1} \mathrm{H}$ NMR spectra in $\mathrm{CD}_{3} \mathrm{CN}$ of $\mathbf{H}_{3} \mathbf{L}$ show drastic changes upon addition of dihydrogenphosphate anions (Figure 2). The thioamide signal $\left(8.86 \mathrm{ppm}\right.$ for free $\left.\mathbf{H}_{\mathbf{3}} \mathbf{L}\right)$ rapidly shift downfield when the concentration of anion is low, but it disappears in an excess of $\mathrm{H}_{2} \mathrm{PO}_{4}^{-}$. On the other hand, the 50 nitrobenzene proton signals $(8.03,7.61$ and $7.49 \mathrm{ppm})$ shift appreciably when anions are added, whereas the phenol protons $(7.29,7.24,7.02 \mathrm{ppm})$ move very little. The other signals change little during the titration experiment. This NMR behaviour is very similar to those observed in the case 55 of fluoride and acetate anions (see ESI).

It has to be noted that only one thiomide $\mathrm{N}-\mathrm{H}$ signal has been observed in the ${ }^{1} \mathrm{H}$ NMR spectrum of the free receptor and, unfortunately, we have not been able to perform ${ }^{13} \mathrm{C}$ NMR experiments with receptor $\mathbf{H}_{3} \mathbf{L}$ in $\mathrm{CD}_{3} \mathrm{CN}$ due to 60 solubility problems. All these drawbacks prevent us from determining exactly which thioamide groups are involved in the adduct formation.

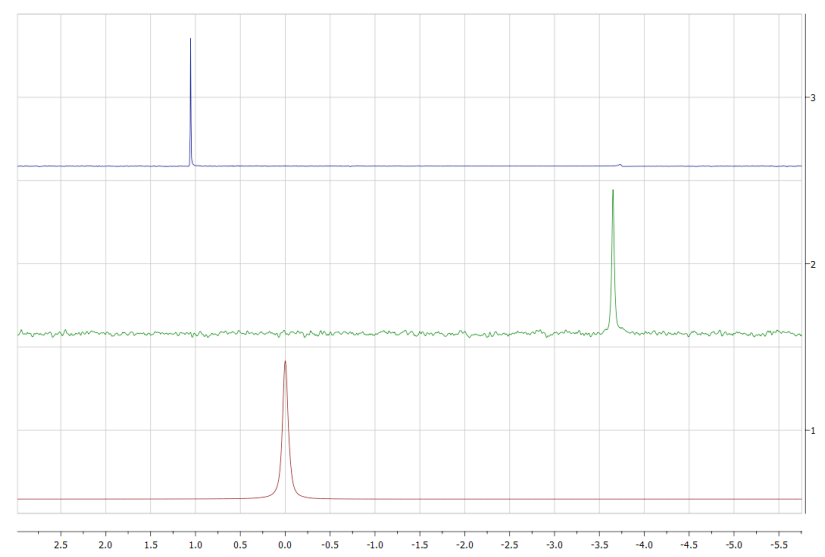

Figure 3. ${ }^{31} \mathrm{P}$ NMR spectra of $\mathrm{CD}_{3} \mathrm{CN}$ solutions of 1$\left.) \mathrm{H}_{3} \mathrm{PO}_{4}(10 \mathrm{mM}), 2\right)$ ${ }_{65} \mathrm{NaH}_{2} \mathrm{PO}_{4}(10 \mathrm{mM})$ and 3) $\mathbf{H}_{3} \mathbf{L}+2$ eq. $\mathrm{NaH}_{2} \mathrm{PO}_{4}(10 \mathrm{mM})$.

At this point, we decided to study the $\mathrm{H}_{2} \mathrm{PO}_{4}{ }^{-}$binding by ${ }^{31} \mathrm{P}$ NMR spectroscopy (Figure 3). The spectrum of $\mathrm{NaH}_{2} \mathrm{PO}_{4}$ in $\mathrm{CD}_{3} \mathrm{CN}$ solution $(10 \mathrm{mM})$ shows a unique signal at -3.6 ppm. An aliquot containg 0.5 eq of the receptor $\mathbf{H}_{3} \mathbf{L}$ was 70 added to this solution. The new ${ }^{31} \mathrm{P}$ spectrum shows a dramatic increase of the chemical shift in the phosphate signal (+4.5 ppm), which can be adscribed to a deshielding effect due to the adduct formation, ${ }^{22}$ as it cannot be adscribed to the formation of $\mathrm{H}_{3} \mathrm{PO}_{4}$.

75 Taking into account all these observations, we suggest that the receptor $\mathbf{H}_{3} \mathbf{L}$ forms $\mathrm{H}$-bonded complexes at low concentrations of dihydrophosphate anion in acetonitrile solution, and that the excess of $\mathrm{H}_{2} \mathrm{PO}_{4}{ }^{-}$causes the deprotonation of the thiourea groups of $\mathrm{H}_{3} \mathbf{L}$.

\section{X-ray studies}

Attempts were made to obtain crystals suitable for X-ray diffraction studies for all the H-bonded complexes of $\mathbf{H}_{3} \mathbf{L}$ investigated in solution. As a general procedure, a $\mathrm{CH}_{3} \mathrm{CN}$ 85 solution containing $\mathbf{H}_{3} \mathbf{L}$ plus an excess of the selected anion was allowed to slowly evaporate at rt. At first, we used their tetrabutylammonium salts as anion source but, after several 
failures, we decided to use the corresponding acids $(1 \%$ of concentrated acid). Suitable crystals were obtained with this last method in the case of the nitrate and trifluoroacetate anions. The main crystallographic data and bond distances are 5 listed in the ESI. Figures 4 and 5 exhibit the stick representations of part of its crystal cells.

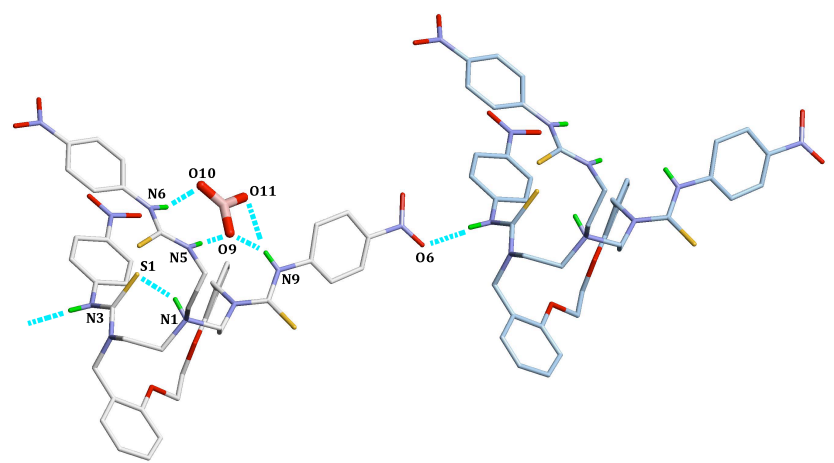

Figure 4. Stick representation of part of the crystal cell of the salt complex $\left[\mathbf{H}_{4} \mathbf{L} \cdots \mathrm{NO}_{3}\right] \cdot\left(\mathrm{CH}_{3} \mathrm{CN}\right)_{4}$, showing the inter and intramolecular $10 \mathrm{H}$-bonds established.

The colourless crystalline product resulted from the crystalization of $\mathbf{H}_{3} \mathbf{L}$ with $\mathrm{HNO}_{3}$ consist of the protonated receptor, a nitrate counterion and four molecules of acetonitrile: $\left[\mathbf{H}_{4} \mathbf{L} \cdots \mathrm{NO}_{3}\right] \cdot\left(\mathrm{CH}_{3} \mathrm{CN}\right)_{4}$. Two of the three 15 thiourea arms of the receptor point their N-H fragments towards the $\mathrm{NO}_{3}^{-}$ion. The only thiourea group equipped with two N-H units establishes with the nitrate a bifurcate interaction $[\mathrm{H} 5 A \cdots \mathrm{O} 91.98(3) \AA ; \mathrm{H} 6 A \cdots \mathrm{O} 10$ 2.12(2) $\AA$ ]. One of the two remain thiourea groups of $\mathbf{H}_{3} \mathbf{L}$ interacts with 20 one of the nitrate oxygens using its single N-H group

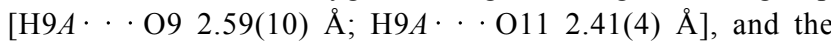
$\mathrm{N}-\mathrm{H}$ group of the third thiourea arm is turned to the outside to allow an $\mathrm{N}-\mathrm{H} \cdots \mathrm{O}$ interaction with one of the oxygen atoms of a nitro group of a neighbor $\mathbf{H}_{3} \mathbf{L}$ molecule $\left[\mathrm{H} 3 \cdots \mathrm{O}^{\mathrm{i}}\right.$ ${ }_{25} 2.10(2) \AA$; symmetry code: (i) $\left.x, y, z+1\right]$. Then, two of the oxygen atoms of $\mathrm{NO}_{3}{ }^{-}$form $\mathrm{H}$-bonds with the $\mathrm{N}-\mathrm{H}$ groups of two of the thiourea arms of $\mathbf{H}_{3} \mathbf{L}$, whereas its third oxygen atom remains unbonded. The four molecules of acetonitrile present in the crystal cell of $\mathbf{H}_{3} \mathbf{L}$, which have been ommitted 30 for clarity in the figures, do not interact with the salt complex.

The crystalization of $\mathbf{H}_{3} \mathbf{L}$ with TFA in acetonitrile was also succesful. In this case the crystal cell consists of the protonated receptor, one $\mathrm{CF}_{3} \mathrm{CO}_{2}{ }^{-}$counterion and two acetonitrile molecules: $\left[\mathrm{H}_{4} \mathbf{L} \cdots \mathrm{CF}_{3} \mathrm{CO}_{2}\right] \cdot\left(\mathrm{CH}_{3} \mathrm{CN}\right)_{2}$. This ${ }_{35}$ crystal structure is very similar to that described above for nitrate. Only two of the three thiourea arms of the receptor interact with the TFA anion. The thiourea group equipped with two N-H units establishes a bifurcate interaction with the $\mathrm{CF}_{3} \mathrm{CO}_{2}^{-}\left[\mathrm{H} 5 \mathrm{~N} \cdots \mathrm{O} 9^{\mathrm{ii}} 2.02(4) \AA ; \mathrm{H} 6 \mathrm{~N} \cdots \mathrm{O} 10^{\mathrm{ii}} 2.11(4) \AA ;\right.$ 40 symmetry code: (ii) $-x+2,-y+1,-z+1]$. Moreover, another thiourea group interacts with one of the oxygens of TFA using its single $\mathrm{N}-\mathrm{H}$ group $\left[\mathrm{H} 9 \mathrm{~N} \cdots \mathrm{O} 9^{\mathrm{ii}} 2.19(5) \AA\right]$. The $\mathrm{N}-\mathrm{H}$ group of the remaining thiourea arm is turned to the outside of the receptor cavity to allow an $\mathrm{N}-\mathrm{H} \cdots \mathrm{N}$ interaction with 45 one acetonitrile molecule $\left[\mathrm{H} 3 N \cdots \mathrm{N} 11^{\mathrm{iii}} 2.14(4) \quad \AA\right.$; symmetry code: (iii) $-x+1,-y+1,-z+1]$. We believe this crystal structure could be useful to speculate about the possible structural rearrangement of the $\mathbf{H}_{3} \mathbf{L}$ :acetate adduct, as $\mathrm{CH}_{3} \mathrm{CO}_{2}{ }^{-}$and $\mathrm{CF}_{3} \mathrm{CO}_{2}^{-}$have almost identical structures.

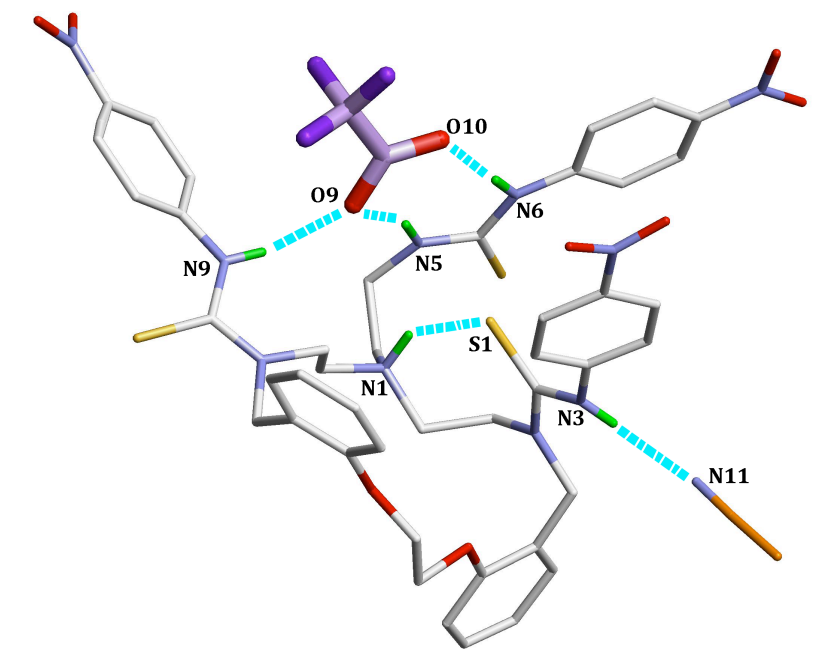

Figure 5. Stick representation of part of the crystal cell of the salt complex $\left[\mathrm{H}_{4} \mathbf{L} \cdots \mathrm{CF}_{3} \mathrm{CO}_{2}\right] \cdot\left(\mathrm{CH}_{3} \mathrm{CN}\right)_{2}$, showing the inter and intramolecular $\mathrm{H}$-bonds established.

\section{${ }_{55}$ Equilibrium constants}

The data collected suggest that changes in the UV/Vis and NMR spectra of $\mathrm{H}_{3} \mathrm{~L}$ in $\mathrm{MeCN}$ in the presence of an excess of fluoride, acetate or dihydrogenphosphate anions is the consequence of the deprotonation of the sensor and the ${ }_{60}$ formation of the anionic specie $\mathbf{L}^{3-}$. Best fitting curves of the UV-Vis titration data were obtained when assuming that the deprotonation process follow the acid-base reaction equilibrium below: ${ }^{14 \mathrm{~b}, 15}$

${ }_{65} \quad \mathbf{H}_{3} \mathbf{L}+3 \mathrm{X}^{-} \leftrightarrow \mathbf{L}^{3-}+3 \mathrm{HX}\left(\beta_{\mathrm{D}}\right)$

This equilibrium is progressively displaced to the right on addition of an excess of $\mathrm{X}^{-}$and the formation of $\left[\mathrm{HX}_{2}\right]$ dimers: $:^{23}$

70

$$
\mathrm{HX}+\mathrm{X}^{-} \leftrightarrow \mathrm{HX}_{2}^{-}
$$

The overall equilibrium, with a stoichiometry of 1:6 for $\mathrm{H}_{3} \mathrm{~L}-\mathrm{X}$ interactions, can be obtained combining eqn (1) and $75(2):^{14 \mathrm{~b}, 15}$

$$
\mathbf{H}_{3} \mathbf{L}+6 \mathrm{X}^{-} \leftrightarrow \mathbf{L}^{3-}+3 \mathrm{HX}_{2}^{-}
$$

This two-step equilibrium can be applied to the ${ }_{80}$ deprotonation processes promoted by the anions $\mathrm{F}^{-}, \mathrm{CH}_{3} \mathrm{CO}_{2}{ }^{-}$ and $\mathrm{H}_{2} \mathrm{PO}_{4}^{-}$, as all of them can form $\mathrm{HX}_{2}^{-}$dimers. ${ }^{11,12,14 \mathrm{~b}, 15,22}$ Interestingly, the value of $\log \beta_{\mathrm{D}}$ (equation 1) for $\mathrm{H}_{2} \mathrm{PO}_{4}$ $[13.32(3)]$ is higher than those calculated for $\mathrm{F}^{-}[11.95(12)]$ and $\mathrm{CH}_{3} \mathrm{CO}_{2}^{-}$[11.94(1)] (see ESI).

85 Since the basicity of these anions decreases on the series $\mathrm{F}^{-}$ $>\mathrm{CH}_{3} \mathrm{CO}_{2}^{-}>\mathrm{H}_{2} \mathrm{PO}_{4}^{-}$, the observed tendency in the value of $\beta_{\mathrm{D}}$ for this system could be only explained on the basis of molecular properties of the receptor-anion interaction. ${ }^{19,21}$ As 
$\beta_{\mathrm{D}}$ is a global deprotonation constant of a stepwise equilibrium which leads to the deprotonated form of the receptor, the stability of the intermediates formed during this process must affect its final value.

Further spectrophotometric studies in $\mathrm{CH}_{3} \mathrm{CN}$ solution showed that $\mathrm{F}^{-}, \mathrm{CH}_{3} \mathrm{CO}_{2}^{-}$and $\mathrm{H}_{2} \mathrm{PO}_{4}^{-}$form $1: 1$ adducts with receptor $\mathbf{H}_{3} \mathrm{~L}$ at low concentration of the corresponding anion:

$$
\mathbf{H}_{3} \mathbf{L}+\mathbf{X}^{-} \leftrightarrow\left[\mathbf{H}_{3} \mathbf{L} \cdots \mathbf{X}\right]^{-}(K)
$$

We have found that the value of $\log K$ (equation 4 ) for $\mathrm{H}_{2} \mathrm{PO}_{4}^{-}$[4.31(14)] is higher than those calculated for $\mathrm{F}^{-}$ [2.21(4)] and $\mathrm{CH}_{3} \mathrm{CO}_{2}^{-}$[3.89(6)] (see ESI). ${ }^{24}$ This suggests that, at low concentrations of anion in the media, the 15 tetrahedral $\mathrm{H}_{2} \mathrm{PO}_{4}{ }^{-}$ion forms a more stable H-bonded complex than the spherical $\mathrm{F}^{-}$or the triangular planar $\mathrm{CH}_{3} \mathrm{CO}_{2}^{-}$with receptor $\mathbf{H}_{3} \mathbf{L}{ }^{25}$ This adduct is capable of out-balancing the more basic contribution of fluoride and, to a lesser degree, acetate anions with respect to dihydrogenphosphate, it is also 20 able to out-balance the higher stability of $\left[\mathrm{HF}_{2}\right]^{-}$and $\left[\mathrm{H}\left(\mathrm{CH}_{3} \mathrm{CO}_{2}\right)_{2}\right]^{-}$self-complexes in comparison to $\left[\mathrm{H}\left(\mathrm{H}_{2} \mathrm{PO}_{4}\right)_{2}\right]$ $12 \mathrm{~b}$

At this point, we decided to carry out molecular modelling studies in order to gain some insight into the structural ${ }_{25}$ features of the $\left[\mathbf{H}_{3} \mathbf{L} \cdots \mathrm{H}_{2} \mathrm{PO}_{4}\right]^{-}$supramolecular adduct. Figure 6 shows the structure of this adduct, as calculated by a semiempirical method (AM1) by using the SPARTAN software. It shows that $\mathbf{H}_{\mathbf{3}} \mathbf{L}$ adopts a cone conformation reminiscent with those of calixarenes, with the $\mathrm{NH}$ donor

30 groups facing the inside. Noticeably, the dihydrogenphospate ion interacts with all the thioamide $\mathrm{NH}$ groups of the $\mathbf{H}_{\mathbf{3}} \mathbf{L}$ receptor. It has to be noted that examples of tripodal receptors such as $\mathbf{H}_{\mathbf{3}} \mathbf{L}$ suitable for accommodating phosphate anions have been previously reported. ${ }^{26}$

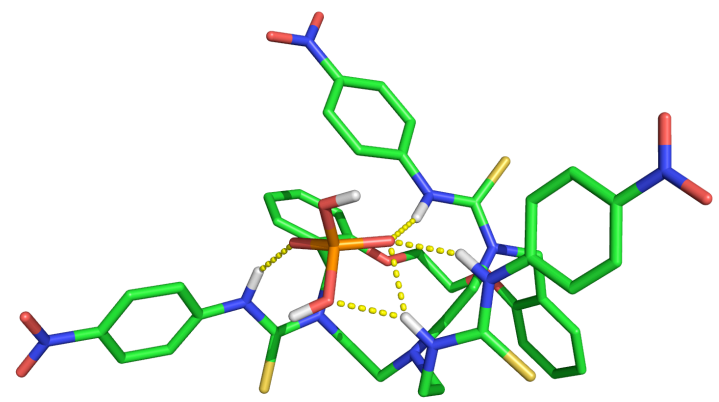

Figure 6. Optimized structure for the $\left[\mathbf{H}_{3} \mathbf{L} \cdots \mathrm{H}_{2} \mathrm{PO}_{4}\right]^{-}$adduct, as calculated with a semiempirical method (AM1) with SPARTAN software, showing the hydrogen-bonding interactions of the dihydrogenphosphate anion with the three thiourea arms of the receptor.

\section{${ }_{40}$ Conclusions}

In summary, we have developed a new colorimetric H-bond sensor based on the deprotonation of its three thiourea donor fragments in the presence of basic inorganic anions such as fluoride, acetate or dihydrogenphosphate. The H-bond ${ }_{45}$ complexation/deprotonation mechanism has been demonstrated by spectrophotometric titrations and by NMR spectroscopy. The equilibrium constants, calculated using the $\mathrm{UV}$-vis titration data, for $\mathrm{H}_{2} \mathrm{PO}_{4}{ }^{-}$are two order of magnitude larger than those for $\mathrm{CH}_{3} \mathrm{CO}_{2}^{-}$and $\mathrm{F}^{-}$, making this receptor so selective for this anion.

The UV-vis and ${ }^{1} \mathrm{H}$ and ${ }^{31} \mathrm{P}$ NMR titration experiments, as well as the $\mathrm{X}$-ray crystal structures of the $\left[\mathbf{H}_{4} \mathbf{L} \cdots \mathrm{NO}_{3}\right] \cdot\left(\mathrm{CH}_{3} \mathrm{CN}\right)_{4}$ and $\left[\mathbf{H}_{4} \mathbf{L} \cdots \mathrm{CF}_{3} \mathrm{CO}_{2}\right] \cdot\left(\mathrm{CH}_{3} \mathrm{CN}\right)_{2}$ salt complexes, ${ }^{24}$ suggest that that the receptor forms $\mathrm{H}$ ${ }_{55}$ bonded complexes of the type $\left[\mathrm{H}_{3} \mathbf{L}^{\cdots \mathrm{A}}\right]^{-}$when the concentration of anion in the media is low (in the case of $\mathrm{F}^{-}$, $\mathrm{CH}_{3} \mathrm{CO}_{2}^{-}$and $\mathrm{H}_{2} \mathrm{PO}_{4}^{-}$), or at high concentrations of the other inorganic anions studied. From the equilibrium constants it seems that the receptor $\mathbf{H}_{3} \mathbf{L}$ forms much more stable $\mathrm{H}$ 60 bonded intermediate complexes with the tetrahedral $\mathrm{H}_{2} \mathrm{PO}_{4}{ }^{-}$ anion than with the spherical $\mathrm{F}^{-}$or the triangular planar $\mathrm{CH}_{3} \mathrm{CO}_{2}^{-}$, which could explain this unusual behavior.

We are currently modifying the structure of $\mathbf{H}_{3} \mathbf{L}$ in order to modulate its affinity and selectivity.

\section{${ }_{65}$ Acknowledgements}

R. B. thanks the Xunta de Galicia (Spain; Projects (PGIDI10PXIB209028PR and INCITE09E1R209058ES). M. V. L. thanks the Directorate-General for Research and Development of the Xunta of Galicia (INCITE09 209084 PR) 70 and the Ministry for Science and Innovation of Spain (CTQ2009-14431/BQU) for finantial support. M. V. L. also thanks M. Eugenio Vázquez (CIQUS) for his help in the molecular modeling studies. G. R. thanks the International Iberian Nanotechnology Laboratory (INL) for a PhD grant.

\section{${ }_{75}$ References}

a Departamento de Química Inorgánica, Facultade de Química, Universidade de Santiago de Compostela, 15782 Santiago de Compostela, Spain.e-mail: mrufina.bastida@usc.es

${ }^{b}$ Servicio de Difracción de Rayos X, Edificio CACTUS, Universidade de 80 Santiago de Compostela, 15782 Santiago de Compostela, Spain

Departmento de Química Inorgánica and Centro Singular de Investigación en Química Biolóxica y Materiais Moleculares (CIQUS), Universidade de Santiago de Compostela, 15782 Santiago de Compostela, Spain.e-mail: miguel.vazquez.lopez@usc.es.

${ }_{85}{ }^{\dagger}$ Electronic supplementary information (ESI) available: Crystallographic data for $\left[\mathrm{H}_{4} \boldsymbol{L} \cdots \mathrm{NO}_{3}\right] .\left(\mathrm{CH}_{3} \mathrm{CN}\right)_{4}$ and $\left[\mathrm{H}_{4} \boldsymbol{L} \cdots \mathrm{CF}_{3} \mathrm{CO}_{2}\right] \cdot\left(\mathrm{CH}_{3} \mathrm{CN}\right)_{2}$. Selected bond distances and angles for $\left[\boldsymbol{H}_{4} \boldsymbol{L} \cdots \mathrm{NO}_{3}\right] \cdot\left(\mathrm{CH}_{3} \mathrm{CN}\right)_{4}$ and $\left[\boldsymbol{H}_{4} \boldsymbol{L} \cdots \mathrm{CF}_{3} \mathrm{CO}_{2}\right] \cdot\left(\mathrm{CH}_{3} \mathrm{CN}\right)_{2} .{ }^{1} \mathrm{H} \quad \mathrm{NMR}$ spectra of $\boldsymbol{H}_{3} \boldsymbol{L} .{ }^{1} \mathrm{H} \quad \mathrm{NMR}$ titrations of $\mathrm{H}_{3} \mathbf{L}$ with $\mathrm{F}, \mathrm{CH}_{3} \mathrm{CO}_{2}^{-}$and $\mathrm{H}_{2} \mathrm{PO}_{4}^{-}$. Spectrophotometric 90 titrations of $\mathrm{H}_{3} \mathbf{L}$ with $\mathrm{OH}^{-}, \mathrm{F}, \mathrm{CH}_{3} \mathrm{CO}_{2}^{-}$and $\mathrm{NO}_{3}^{-}$. Fit of the equilibrium constants calculated for $\mathrm{F}-, \mathrm{CH}_{3} \mathrm{CO}_{2}^{-}$and $\mathrm{H}_{2} \mathrm{PO}_{4}^{-}$. CCDC reference numbers 833635 (nitrate salt) and 863706 (TFA salt).

1 (a) Supramolecular Chemistry of Anions (Eds. : A. Bianchi, K. 95 Bowman-James and E. García-España), Wiley-VCH, New York, 1997; (b) P. D. Beer, Acc. Chem. Res., 1998, 31, 71; (c) C. R. Bondy and S. J. Loeb, Coord. Chem. Rev., 2003, 240, 77; (d) P. A. Gale and R. Quesada, Coord. Chem. Rev., 2006, 250, 3219; (e) C. Suksai and T. Tuntulani, Chem. Soc. Rev., 2003, 32, 192; (f) C. Bowman-James, Acc. Chem. Res., 2005, 38, 671; (g) T. Gunnlaugsson, M. Glynn, G. M. Tocci, P. E. Kruger and F. M. Pfeffer, Coord. Chem. Rev., 2006, 250, 3094; $(h)$ V. Amendola, D. Esteban Gómez, L. Fabbrizzi and M. Licchelli, Acc. Chem. Res., 2006, 39, 343; (i) R. Martinez-Máñez and F. Sancenon, Chem. Rev. 2003, 103, 441; (j) J. L. Sessler and J. M. 105 Davis, Acc. Chem. Res. 2001, 34, 989; (k) M. Berger and F. P. Schmidtchen, Chem. Rev., 1997, 97, 1609.

2 a) The Biochemistry of Nucleic Acids, 10th ed. (Eds.: R. L. P. Adams, J. T. Knower and D. P. Leader), Chapman and Hall, New 
York, 1986; b) W. Saenger, Principles of Nucleic Acid Structure, Springer, New York, 1998.

3 a) M. E. Huston, E. U. Akkaya, A. W. Czarnik, J. Am. Chem. Soc., 1989, 111, 8735; b) P. Schiessl and F. P. Schmidtchen, J. Org. Chem., 1994, 59, 510; c) L. Fabrizzi, N. Marcotte, F. Stomeo and A. Taglietti, Angew. Chem. Int. Ed., 2002, 41, 3811; d) T. Gunnlaugsson, A. P. Davis, J. E. O'Brien and M. Glynn, Org. Lett., 2002, 4, 2449; e) H. Kwan Cho, D. Hoon Lee and J.-I. Hong, Chem. Commun., 2005, 1690.

104 (a) A. B. Descalzo, K. Rurack, H. Weisshoff, R. Martinez-Máñez, M. D. Marcos, P. Amoros, K. Hoffmann and J. Soto, J. Am. Chem. Soc., 2005, 127, 184; (b) V. Amendola, L. Fabbrizzi and L. Mosca, Chem. Soc. Rev., 2010, 39, 3889.

5 T. Gunnlaugsson, A. P. Davis, G. M. Hussey, J. Tierney and M. Glynn, Org. Biomol. Chem., 2004, $2,1856$.

6 P. A. Gale, Chem. Commun., 2005, 37

7 (a) M. A.Hossain, S. O. Kang, J. M. Llinares, D. Powelland and K. Bowman-James, Inorg. Chem., 2003, 42, 5043

8 J. L. Sessler, M. J. Cyr, V. Lynch, E. McGhee and J. A. Ibers, J. Am. Chem. Soc., 1990, 112, 2810.

9 T. Steiner, Angew. Chem., Int. Ed., 2002, 41, 48.

10 R. M. Duke, J. E. O’Brien, T. McCabe and T. Gunnlaugsson, Org. Biomol. Chem., 2008, 6, 4089.

11 S. Gronert, J. Am. Chem. Soc., 1993, 115, 10258

2512 a) M. J. Barrow, M. Currie, K. W. Muir, J. C. Speakman and D. N. J. White, J. Chem. Soc., Perkin Trans. 2, 1975, 15; b) D. EstebanGómez, L. Fabbrizzi, M. Licchelli and E. Monzani, Org. Biomol. Chem., 2005, 3, 1495.

13 M. Vázquez, L. Fabbrizzi, A. Taglietti, R. M. Pedrido, A. M.

30 González-Noya and M. R. Bermejo, Angew. Chem., Int. Ed., 2004, 43, 1962

14 a) T. Gunnlaugsson, A.P. Davis, J.E. O'Brien and M. Glynn, Org Biomol. Chem., 2005, 3, 48; b) Y. Wu, X. Peng, J. Fan, S. Gao, M. Tian, J. Zhao and S. Sun, J. Org. Chem., 2007, 72, 62.

3515 M. Vázquez López, M. R. Bermejo, M. E. Vázquez, A. Taglietti, G. Zaragoza R. Pedrido and Miguel Martínez-Calvo, Org. Biomol. Chem., 2010, 8, 357-362

16 V. Amendola, M. Boiocchi, D. Esteban-Gómez, L. Fabbrizzi and E. Monzani, Org. Biomol. Chem., 2005, 3, 2632.

4017 H. Keypour and F. A. Araey, Asian J. Chem., 2007, 19, 2873.

18 G. M. Sheldrick, SADABS, Program for Empirical Absorption Correction of Area Detector Data, University of Göttingen, Germany, 1996.

19 A. Altomare, M. C. Burla, M. Camalli, G. L. Cascarano, C.

45 Giacovazzo, A. Guagliardi, A. G. G. Moliterni, G., Polidori and R. Spagna, J. Appl. Cryst., 1999, 32, 115.

20 G. M. Sheldrick, SHELX-97, An Integrated System for Solving and Refining Crystal Structures from Diffraction Data, University of Göttingen, Germany, 1997.

5021 M. Boiocchi, L. del Boca, D. Esteban-Gómez, L. Fabbrizzi, M. Licchelli and E. Monzani, J. Am. Chem. Soc., 2004, 126, 16507

22 D. M. Rudkevich, W. Verboom, Z. Brzozka, M. J. Palys, W. P. R. V. Stauthamer, G. J. van Hummel, S. M. Franken, S. Harkema, J. F. J. Engbersen and D. N. Reinhoudt, J. Am. Chem. Soc., 1994, 116, 4341.

5523 a) V. Amendola, M. Boiocchi, L. Fabbrizzi and A. Palchetti, Chem. Eur. J., 2005, 11, 5648; b) M. Boiocchi, L. del Boca, D. EstebanGómez, L. Fabbrizzi, M. Licchelli and E. Monzani, Chem.-Eur. J., 2005, 11, 3097; (c) R. M. Duke, J. E. O'Brien, T. McCabe and T. Gunnlaugsson, Org. Biomol. Chem., 2008, 6, 4089.

6024 H. Gampp, M. Maeder, C. J. Meyer and A. D. Zuberbuehler, Talanta, 1985, 32, 1133.

25 a) S. O. Kang, R. A. Begum, K. Bowman-James, Angew. Chem. Int. Ed. 2006, 45, 7882; b) E. A. Katayev, J. L. Sessler, V. N. Khrustalev and Y. A. Ustynyuk, J. Org. Chem., 2007, 72, 7244.

${ }_{65} 26$ a) A. Pramanik and G. Das, Tetrahedron, 2009, 65, 2196; b) H. Xie, S. Yi, X. Yang and S. Wu, New J. Chem., 2009, 23, 1105. 